\title{
Exploring the anti-HIV-1 reverse transcriptase, anti-inflammatory, anti-cancer activities and cytotoxicity of two fermented commercial herbal concoctions sold in Limpopo Province of South Africa
}

Matimba I. Ntlhamu', Ashwell R. Ndhlala $2^{2^{*}}$ and Peter Masoko ${ }^{1 *}$

\begin{abstract}
Background and objectives: The use of herbal concoctions is very popular in South Africa, including Limpopo Province. The herbal concoctions are claimed to be capable of treating numerous illnesses such as ulcers, cancer, HIV/AIDS, diabetes, certain STDs, blood cleansing to mention but a few. The focus of this study was to evaluate the anti-HIV 1 reverse transcriptase, anti-inflammatory and anti-cancerous activities as well as cytotoxic effects of 2 fermented herbal concoctions used for the treatment of the related ailments in Limpopo province of South Africa.

Method: Two fermented herbal concoctions obtained from a herbalist in Polokwane were extracted with 80\% acetone. The anti-HIV activity of the herbal concoctions was determined using the anti-HIV reverse transcriptase assay. The anti-cancer and cytotoxic effects of the herbal concoctions were evaluated using cancerous Human Colon (HT-29) cells and the normal human Hepatoma cells (C3A) respectively.

Results: Notable anti-HIV reverse transcriptase activity was observed from the $80 \%$ acetone fraction of herbal concoction $1\left(I C_{50} 38.031 \mu \mathrm{g} / \mathrm{mL}\right)$ which exhibited better activity than the positive control Lamivudine $\left(I C_{50}\right.$ $40.90 \mu \mathrm{g} / \mathrm{mL}$ ). There was variation in the anti-inflammation activity as determined by the sPL2, 15-LOX and COX enzyme assays. The only concerning matter was the high COX-1 activity in some of the extracts, which is not desirable due to the mucosal protection action of COX-1 enzyme. The herbal concoctions did not exhibit cytotoxic effects on normal human cells, however, toxicity against cancerous cells was observed.

Conclusion: The herbal concoctions displayed some considerable pharmacological effects against various ailments as claimed by the herbalist. More work to ascertain the toxicity of both concoctions against cancerous cells need to be followed as this could lead to the discovery of anticancer drugs.
\end{abstract}

Keywords: Anti-HIV-1 reverse transcriptase, Cytotoxicity, Anti-cancer, Fermented herbal concoctions

\footnotetext{
*Correspondence: Ashwell.Ndhlala@ul.ac.za; Peter.Masoko@ul.ac.za

${ }^{2}$ Green Biotechnologies Research Centre of Excellence, Faculty of Science and Agriculture, University of Limpopo, Private Bag X1106, Sovenga, Limpopo 0727, South Africa

'Department of Biochemistry, Microbiology and Biotechnology, Faculty of Science and Agriculture, University of Limpopo, Private Bag X1106, Sovenga, Limpopo 0727, South Africa
}

(c) The Author(s). 2021 Open Access This article is licensed under a Creative Commons Attribution 4.0 International License, which permits use, sharing, adaptation, distribution and reproduction in any medium or format, as long as you give appropriate credit to the original author(s) and the source, provide a link to the Creative Commons licence, and indicate if changes were made. The images or other third party material in this article are included in the article's Creative Commons licence, unless indicated otherwise in a credit line to the material. If material is not included in the article's Creative Commons licence and your intended use is not permitted by statutory regulation or exceeds the permitted use, you will need to obtain permission directly from the copyright holder. To view a copy of this licence, visit http://creativecommons.org/licenses/by/4.0/ The Creative Commons Public Domain Dedication waiver (http://creativecommons.org/publicdomain/zero/1.0/) applies to the data made available in this article, unless otherwise stated in a credit line to the data. 


\section{Background}

Since ancient times, plants have been used as medicine throughout the world [1]. In South Africa, there is great cultural diversity and several ethnic groups, which results in the massive use of medicinal plants throughout the provinces [2]. Each cultural group in South Africa has different medical solutions for the prevention and curing of the same disease [3]. Hence, several ethnic groups use traditional knowledge to cure various infectious diseases caused by parasites, bacteria and viruses in addition to the treatment of poisonings caused by snakes and scorpions as well as skin diseases, inflammations, bronchial conditions, fever and pains [4-6].

The World Health Organization (WHO) has estimated that $80 \%$ of the world's population use traditional medicine for their health care needs and it commonly requires the use of herbal extracts and their active components. There are approximately 20,000 herbal plants in the world used for medicinal purposes [7]. In South Africa, there are 30,000 species of higher plants and there are approximately 350 species which are traded as medicinal plants [8].

Medicinal plants used traditionally to treat infectious diseases seem to be an abundant source of new bioactive secondary metabolites. Therefore, more effective antimicrobial agents with novel modes of action must be discovered and developed. The World Health Organization (WHO) recommended that traditional healers be included in national responses to HIV/AIDS [9]. As early as 1989, WHO had appealed to the need to evaluate ethnomedicine for the management of HIV/ AIDS. In this regard, several studies have reported antiHIV potential of medicinal plants and their derivatives.

Traditionally, plant medicines are often used as extracts, where some of these extracts are a mixture of different plant parts, commonly referred to as herbal concoctions. Concoctions could also be some simple and common homemade remedies made to treat minor illnesses as well as complex remedies used to treat major and life-threatening illnesses [10] (Cano and Volpato, 2004). In South Africa, concoctions are used as traditional medicines as it is claimed that they possess disease healing properties such as HIV/AIDS and other related infections [11]. Plant parts commonly used for the preparation of herbal concoctions include stems, leaves, roots, bark, etc. [12]. Different methods are used to prepare herbal concoctions, starting from simple brewing processes to more complex techniques that use alcohol and other organic solvents to extract plant compounds [13]. Fermentation is a microorganism driven process which yields high value product from raw or low-grade substrates. Hence some herbal products are fermented in order to break down or convert the undesirable substrates into compatible components under the action of microbial enzymes, thereby improving the substrate properties via the production and enrichment of bioactive compounds. In addition, fermentation improves the nutrient values of foods and breaks them down into more easily catabolisable forms [14]. The advantage of concoctions lies in their composition as rich mixtures of different plants. Furthermore, the herbal concoctions possess synergistic and additive pharmacological effects that result from mixing different plants [15]. Herbal products of cooperate manufacturers have standard formulae; they are fully labelled according to how they are used and are stored in appropriate conditions whereas those from herbalists are just prepared and stored like the ones at muthi shop owners and street vendors. Hence the poor regulations of these concoctions pose a threat to customer's health.

The HIV epidemic continues to be a major global public health issue. In the year 2017, there were 25.7 million people living with HIV/AIDS in Sub-Saharan Africa, accounting for two-thirds of new HIV infections globally [16]. The Joint United Nations Programme on HIV/ AIDS (UNAIDS) FastTrack strategy aims to increase the HIV response in low and middle-income countries to end the epidemic by 2030 [17]. A study has previously shown that most people living with HIV/AIDS are susceptible to fungal and bacterial opportunistic infections that result from immunosuppression [18]. South African health researchers and clinicians have been actively involved in human immunodeficiency virus (HIV) research for more than three decades now, with prevention and treatment as the main focus [19].

Moreover, the use of medicinal plants is associated with irritation of the gastrointestinal tract, destruction of red blood cells and damage of the heart and kidney [20]. Therefore, this necessitates the need for toxicity evaluation of herbal concoctions used in ethnopharmacology. In vitro, toxicological studies use a wide number of assays to determine cytotoxicity that comes from the exposure of chemical substances [21].

It has been reported by the World Health Organisation (WHO), that cancer is one of the leading causes of morbidity and mortality worldwide [22]. Cancer, according to the National Cancer Institute (NCI) of the United States of America, is described as a collection of associated diseases. It results from uncontrollable cell division which leads to deregulation between cell death and cell proliferation. This leads to formation of tumours, as cells that should have died did not receive the signal to do so [23]. These tumours can either be malignant or benign [24]. Malignant tumours contain cells that are capable of detaching, migrating and forming secondary tumours in other parts of the body. In contrast, benign tumours have cells that proliferate and remain at the site of origin [25]. 
A global increase of $1 \%$ in cancer-related deaths was reported between the years 2011 and 2013. These cases are expected to increase by $46 \%$ over the next 13 years [26]. Hence due to the high cancer mortality rate, the development of drug resistance, as well as undesirable side effects, there is a pressing need to search for and/or develop new anti-cancer drugs [27]. There exist several pervasive developments in methods for synthesis of cancer therapeutic drugs in the pharmaceutical industry, however, medicinal plants still represent important sources of new molecular identities. This is because plants can synthesise and produce components that are burdensome to obtain through chemical synthesis and this makes them an important source for the development of new anticancer drugs that would perhaps selectively kill cancerous cells [28].

The National Cancer Institute-USA has screened roughly 35,000 plant species for potential anticancer activities. Amongst these, approximately 3000 plant species were found to have anticancer activity [29]. There is still a large reservoir of bioactive compounds, however, only a few have been examined thus far and continue to be a principal potential source of anticancer agents [30].

In the Limpopo Province (Mankweng), there is a strong rise of herbal medicine production and trading by herbalists. The herbalists primarily sell herbal concoctions which apart from being prescribed for the treatment of HIV, ulcers and cancer, they are claimed to have aphrodisiac, immune-boosting and blood cleansing effects, however, the efficacy and safety of the concoctions have not been validated. It is therefore the objective of this study to validate the anti-HIV properties of the fermented herbal concoctions and the potentially toxic effects that may arise from the consumption of the concoctions and will be evaluated through the determination of cell viability after 24-h exposure.

\section{Methods}

\section{Concoction preparation}

Two commercially available fermented herbal concoctions were supplied by an herbalist (Mr. MS Mathebula) based at the University of Limpopo. Once procured, the fermented herbal concoctions were separately subjected to a stream of cold air to drive out any alcohol by products before freeze drying. The dried samples were partitioned into two from each herbal product, the crude extract while the other portion was extracted with $80 \%$ acetone. The crude extracts were reconstituted with water and the other with $80 \%$ aqueous ethanol. The former considered as the crude and the latter, regarded as a sub fraction. Table 1 list the plant material used to produce the herbal concoctions. The collection of plant materials by the herbalist is done in compliance with the guidelines set in the South African Bureau of Standards on collection and harvesting of Medicinal plants (SANS ARP 029:2013).

\section{HIV-1 reverse transcriptase (RT) inhibitory bioassay}

The effect of the herbal preparations on reverse transcription was evaluated using a non-radioactive HIV-RT colorimetric ELISA kit obtained from Roche Diagnostics, Germany and detailed by Ndhlala et al. [31] with modifications [32]. The protocol supplied together with the kit was followed, under nuclease-free conditions. The reverse transcriptase colorimetric assay takes advantage of the ability of RT to synthesize DNA, starting from the template/primer hybrid poly $(\mathrm{A}) \times$ oligo $(\mathrm{dT}) 15$. The kit avoids the use of $\left[{ }^{3} \mathrm{H}\right]-$ or $\left[{ }^{32} \mathrm{P}\right]$-labelled nucleotides which are used for the other classical RT assays. In place of radio-labelled nucleotides, digoxigenin- and biotinlabelled nucleotides are incorporated into one and the same DNA molecule, which is freshly synthesised by the RT. The detection and quantification of synthesized DNA as a parameter for RT activity is followed in a sandwich ELISA protocol: Biotin-labelled DNA freshly synthesised by the RT binds to the surface of microtiter plate modules (MPM) with wells that were precoated with streptavidin. In the next step, an antibody to digoxigenin, conjugated to peroxidase (anti-DIG-POD), binds to the digoxigenin-labelled DNA. In the final step, the peroxidase substrate ABTS (2, 2'-Azinobis [3-ethylbenzothiazoline-6-sulfonic acid]- diammonium salt) is added. The peroxidase enzyme catalyses the cleavage of the substrate, producing a coloured reaction product which is measured spectrophotometrically.

The following solutions provided with the kit were prepared according to the manufacturer; Solution 1, HIV-1 reverse transcriptase (final concentration $2 \mathrm{ng} / \mu \mathrm{L}$,

Table 1 Plant species used as ingredients of two fermented commercial herbal concoctions

\begin{tabular}{llll}
\hline $\begin{array}{l}\text { Herbal } \\
\text { Mixture }\end{array}$ & Plant composition & & Plant part \\
\cline { 2 - 3 } & Family name & Scientific name & Leaf \\
\hline 1 & Geraniaceae & Monsonia angustifolia E.Mey. ex A.Rich. & Seed \\
& Oleaceae & Olea europaea L. & Leaf + Stem \\
& Fabeae & Lens esculentum Mill. & leaf \\
& Moringaceae & Moringa oleifera Lam. & Fruit pulp \\
\hline
\end{tabular}


corresponding to $10 \mathrm{mU} / \mu \mathrm{L}$ ) stored at $-70^{\circ} \mathrm{C}$. Solution 2 , incubation buffer. Solution 3, reaction mixture containing poly (A) x oligo (dT) $15(46 \mathrm{mM}$ Tris- $\mathrm{HCl}, 266$ $\mathrm{mM}$ potassium chloride, $27.5 \mathrm{mM}$ magnesium chloride, $9.2 \mathrm{mM}$ DDT, $10 \mu \mathrm{M}$ dUTP/dTTP, template/primer hybrid, $750 \mathrm{~mA} 260 \mathrm{~nm} / \mathrm{mL}$ ). Solution 4, lysis buffer. Solution 5, anti-digoxigenin-peroxidase (anti-DIG-POD) $(200 \mathrm{mU} / \mathrm{mL})$. Solution 6 , washing buffer and solution 7 , ABTS substrate solution. In sterile Eppendorf tubes, $20 \mu \mathrm{L}$ of resuspended herbal preparations (with final assay concentrations of $0.25,2.5,25,250,2500 \mu \mathrm{g} / \mathrm{mL}$ ) or controls were mixed with $20 \mu \mathrm{L}$ of recombinant HIV1-RT (4 ng in lysis buffer) and $20 \mu \mathrm{L}$ reaction mixture (solution 3 ) and the tubes were incubated for $1 \mathrm{~h}$ at $37^{\circ} \mathrm{C}$. After the $1 \mathrm{~h}$ incubation period, the contents of the tubes $(60 \mu \mathrm{L})$ were transferred into MPM wells. The MPM was covered with foil and incubated for $1 \mathrm{~h}$ at $37{ }^{\circ} \mathrm{C}$ after which the contents were removed from the MPM wells completely. The wells were rinsed 5 times with $250 \mu \mathrm{L}$ of washing buffer (solution 6) per well for $30 \mathrm{~s}$, with the washing buffer being removed carefully after each wash. After the wash, $200 \mu \mathrm{L}$ of anti-DIGPOD (solution 5) was added to each well and the MPM was re-covered with foil and incubated for $1 \mathrm{~h}$ at $37^{\circ} \mathrm{C}$. After the incubation period, the solution was removed completely from the MPM wells. The MPM wells were rinsed 5 times with $250 \mu \mathrm{L}$ of washing buffer (solution 6) per well for $30 \mathrm{~s}$, the washing buffer was removed carefully after each wash. After washing, $200 \mu \mathrm{L}$ of ABTS substrate solution (solution 7) was added to each well and the MPM was incubated at room temperature for 5 min (a green colour appeared in the wells). The absorbance of the reaction mixture was then measured at 405 $\mathrm{nm}$ (reference wavelength: $490 \mathrm{~nm}$ ) using a microplate reader (Opsys MR ${ }^{\mathrm{Tx}}$, Dynex Technologies Inc.). Percentage of inhibition was calculated by comparing the absorbance of the sample to the negative control using the equation below:

HIV-1 RT inhibition $(\%)=\left\{1-\left(\frac{\mathrm{Abs}_{405} \mathrm{~nm} \text { Sample }}{\mathrm{Abs}_{405} \mathrm{~nm} \text { Neg Control }}\right)\right\} \times 100$

where $\mathrm{Abs}_{405 \mathrm{~nm}}$ Sample is the absorbance of the reaction with herbal preparations or positive control at $405 \mathrm{~nm}$ and $\mathrm{Abs}_{405 \mathrm{~nm}} \mathrm{Neg}$ Control is the absorbance of reaction with water instead of the sample at $405 \mathrm{~nm}$.

Three tubes containing water instead of the sample were used as negative controls. Combivir ${ }^{\circ}$ (GlaxoSmithKline) [lamivudine $(1.0 \mathrm{mg} / \mathrm{mL})+$ zidovudine $(2.0$ $\mathrm{mg} / \mathrm{mL})$ ] and Kaletra ${ }^{\circ}$ (Abbott) [lopinavir $(8.9 \mathrm{mg} / \mathrm{mL})+$ ritonavir $(2.2 \mathrm{mg} / \mathrm{mL})]$ were used as positive controls.

Results were presented as means duplicates \pm standard deviations of 2 independent experiments; each experiment was done in duplicate. The $\mathrm{IC}_{50}$ values of herbal preparations were calculated using Graph Pad Prism (version 5.0).

\section{Anti-inflammatory assay Secretory phospholipase (sPLA2) inhibitory activity assay} The anti-inflammatory activity of the herbal concoctions was evaluated by examining the inhibition of the human sPLA2 enzyme using the sPLA2 (Type V) inhibitor screening assay kit (Cayman Chemical, Ann Arbor, MI) as described by George et al., [33] with modifications [34]. The assay measures free 5-thio-2-nitrobenzoic acid (TNBA) following hydrolysis of diheptanoylthiophosphatidylcholine (PC) by sPLA2. Briefly, $10 \mu \mathrm{L}$ of the sPLA2 was dissolved in assay buffer solution $(25 \mathrm{mM}$ Tris- $\mathrm{HCl}, 10 \mathrm{mM} \mathrm{CaCl} 2,100 \mathrm{mM} \mathrm{KCl}, 0.3 \mathrm{mM}$ Triton $\mathrm{X}-100, \mathrm{pH} 7.5)$ and $10 \mu \mathrm{L}$ of concoction extract at concentrations of $50,25,12.5$ and $6.25 \mu \mathrm{g} / \mathrm{mL}$ were added into a 96-well microtiter plate. The reaction was initiated by adding $200 \mu \mathrm{L}$ of a substrate solution (diheptanoyl thio- $\mathrm{PC}, 1.66 \mathrm{mM}$ ), covered with aluminium foil and incubated at $25^{\circ} \mathrm{C}$ for $15 \mathrm{~min}$. After incubation, $10 \mu \mathrm{L}$ of DTNB (5,5'-dithio-bis-2-nitrobenzoic acid; $10 \mathrm{mM}, 0.4$ $\mathrm{M}$ Tris- $\mathrm{HCl}, \mathrm{pH}$ 8.0) was added into each well. The reaction mixture containing the assay buffer and solvent served as the blank and mixture with sPLA2 enzyme and solvent served as the $100 \%$ initial activity (IA). Thioetheramide-PC served as the positive control. The hydrolysed diheptanoyl thio-PC was measured at $420 \mathrm{~nm}$ using a microplate reader (Optic Iveymen ${ }^{\circ}$ System, Model 2100-C). The percentage inhibition was calculated using the formula below. The percentage inhibition was plotted against plant extract concentration and the $\mathrm{IC}_{50}$ was determined from the normalised logarithmic regression curve.

$$
\text { sPLA }_{2} \% \text { Inhibition }=[(100 \% \text { IA-Inhibition }) / 100 \% \mathrm{IA} \times 100]
$$

where IA is inhibition absorbance.

\section{Lipoxygenase (15-LOX) inhibitory activity assay}

The anti-inflammatory activity of the herbal concoctions was evaluated by examining the inhibition of the 15LOX enzyme using the LOX inhibitor screening assay kit (Cayman Chemical, Ann Arbor, MI) as described by Boudjou et al. [35] with modifications [34]. The assay measures hydroperoxides produced in the lipoxygenation reaction using purified 15-LOX. Briefly, $90 \mu \mathrm{L}$ of 15-LOX was dissolved in assay buffer solution $(0.1 \mathrm{M}$ Tris- $\mathrm{HCl}, \mathrm{pH} 7.4)$ and $10 \mu \mathrm{L}$ concoctions extract at a concentration of $(50,25,12.5$ and $6.25 \mu \mathrm{g} / \mathrm{mL})$ was added into each well of a 96-well microtiter plate. The plate was incubated at $25^{\circ} \mathrm{C}$ for $5 \mathrm{~min}$. After incubation, the reaction was initiated by adding $10 \mu \mathrm{L}$ substrate solution of arachidonic acid (1 $\mathrm{mM})$ and mixed on a shaker 
for $10 \mathrm{~min}$. The reaction was stopped by adding $100 \mu \mathrm{L}$ of the chromogen into each well. The reaction mixture containing the assay buffer served as the blank and mixture with 15-LOX and solvent served as the 100\% IA. Nordihydroguairetic acid (NDGA) served as a positive control. The absorbance was measured at $490 \mathrm{~nm}$ using a microplate reader (Optic Iveymen ${ }^{\circ}$ System, Model 2100-C). The percentage inhibition was calculated using the formula below. The percentage inhibition was plotted against concoction extract concentration and the $\mathrm{IC}_{50}$ determined from the normalised logarithmic regression curve.

LOX $\%$ Inhibition $=[(100 \%$ IA-Inhibition $) / 100 \% \mathrm{IA} \times 100$

where IA is inhibition absorbance.

\section{Cyclooxygenase (COX-1 and COX-2) inhibitor screening assay}

The anti-inflammatory activity of the two herbal concoctions was evaluated by examining the inhibition of the ovine COX-1 and human COX-2 enzyme using the COX inhibitor screening assay kit (Cayman Chemical, Ann Arbor, MI) as described by Boudjou et al. [35] with modifications [34]. The assay measures the peroxidase activity of ovine COX-1 and human COX-2, by monitoring the appearance of oxidised $\mathrm{N}, \mathrm{N}, \mathrm{N}^{\prime}, \mathrm{N}^{\prime}$-tetramethyl-p-phenylenediamine (TMPD). Briefly, $150 \mu \mathrm{L}$ assay buffer (0.1 MTris- $\mathrm{HCl}, \mathrm{pH} 8), 10 \mu \mathrm{L}$ heme and $10 \mu \mathrm{L}$ ovine COX-1 enzyme was added to each well of the 96-well microtiter plate. The same procedure was repeated with the human COX-2 enzyme. A volume of $10 \mu \mathrm{L}$ concoction extract at a concentration of 50,25 , 12.5 and $6.25 \mu \mathrm{g} / \mathrm{mL}$ was added to each well. The plate was carefully mixed by shaking for $30 \mathrm{~s}$ and followed by incubation at $25^{\circ} \mathrm{C}$ for $5 \mathrm{~min}$. After incubation, $20 \mu \mathrm{L}$ of TMPD was added to each well of the 96-well microtiter plate and the reaction was initiated by the addition of $20 \mu \mathrm{L}$ arachidonic acid. The plates were further incubated at $25^{\circ} \mathrm{C}$ for $5 \mathrm{~min}$. The reaction mixture containing assay buffer and heme served as the blank and a mixture with either COX-1 or COX-2 enzyme, assay buffer and heme served as the 100\% IA. Indomethacin served as a positive control. The absorbance of oxidised TMPD was read at $490 \mathrm{~nm}$ using a microplate reader (Optic Iveymen ${ }^{\circ}$ System, Model 2100-C). The percentage inhibition was calculated using the formula below. The percentage inhibition was plotted against concoction extract concentration and the $\mathrm{IC}_{50}$ was determined from the normalised logarithmic regression curve. Data were expressed as means of duplicates \pm standard deviations.

COX $\%$ Inhibition $=[(100 \% \mathrm{IA}-$ Inhibitor $) / 100 \% \mathrm{IA} \times 100$

where IA is inhibition absorbance.

\section{Cytotoxicity and anti-cancer assay}

To determine the toxicological outcomes of the consumption of the concoctions, their cytotoxic effect on normal human hepatoma cell lines (C3A). The anticancer effect of the herbal concoctions was evaluated on human colon (HT-29) cancer cells. The 3-(4,5-dimethylthiazol-2-yl)-2,5-diphenyltetrazolium bromide (MTT) colorimetric assay described by Mosmann [36] was performed with modifications [34]. Human colon (HT-29) cancer cells and human hepatoma cell lines (C3A) (ATCC ${ }^{\circ}$ HTB-38) (Biosafety level 2) were purchased from the American Type Culture Collection (ATCC). The cells were maintained in a flask with Dulbecco's 0QModified Eagle's Medium (DMEM), (Whitehead Scientific) supplemented with $10 \% \mathrm{v} / \mathrm{v}$ foetal bovine serum (FBS) (Adcock-Ingram) in a cell culture incubator at $37^{\circ} \mathrm{C}$ in humidified air containing $5 \%$ carbon dioxide $\left(\mathrm{CO}_{2}\right)$. Cells $(1 \times 105$ cells $/ \mathrm{mL})$ were seeded in a 96-well plate and allowed to attach overnight in a cell culture incubator. Cells were then treated with various concentrations $(100-900 \mu \mathrm{g} / \mathrm{mL})$ of different herbal concoctions for $24 \mathrm{~h}$. Following treatment, $20 \mu \mathrm{L}$ of $5 \mathrm{mg} / \mathrm{mL}$ MTT was added and the cells were further incubated for $4 \mathrm{~h}$. The MTT solution was then removed and $200 \mu \mathrm{L}$ of dimethyl sulfoxide (DMSO) was added to dissolve the MTT formazan crystals. Purple formazan crystals are formed when MTT is reduced by metabolically active cells. Thus, the number of formed formazan products produced indicates the number of viable cells. For quantification, the absorbance was measured at $560 \mathrm{~nm}$ using the GloMax ${ }^{\circ}$-Multi+Detection System microtitre plate reader (Promega).

\section{Statistical analysis}

The data were expressed as mean \pm standard deviation (S.D). Statistically significant differences between the untreated control and treatments were determined using the GraphPad Software (Version 5, San Diego, CA). Samples were treated to one-way ANOVA, followed by Dunnett's comparison test. Differences between means of untreated, treated cells were considered significant at $p \leq 0.05\left(^{(*)}\right.$ and highly significant at $p \leq 0.01{ }^{(* *)}$.

\section{Results and discussion}

The human immune-deficiency virus (HIV)-1 reverse transcriptase is a very important enzyme in the HIV lifecycle, it transcribes its ribonucleic acid (RNA) code to synthesise a viral deoxyribonucleic acid (DNA) that invades other cells [37]. Therefore, this makes it a crucial target towards the screening and development of antiretroviral drugs against HIV. The anti-HIV potential of othe herbal concoctions was evaluated by determining their capability to inhibit the HIV-1 reverse transcriptase (RT) activity. The concentration of an inhibitor that can 
produce half $(50 \%)$ maximal activity was denoted as $\mathrm{IC}_{50}$. Therefore, the smaller the concentration $\left(\mathrm{IC}_{50}\right)$ of a drug required to inhibit HIV-RT whilst exhibiting minimum or no toxicities can be considered for pharmaceutical development. Four levels of activity were defined as follows: activity below $25 \mu \mathrm{g} / \mathrm{mL}$ being considered high activity, $25-50 \mu \mathrm{g} / \mathrm{mL}$ good activity, $50-100 \mu \mathrm{g} / \mathrm{mL}$ moderate activity and above $100 \mu \mathrm{g} / \mathrm{mL}$ low activity. These levels of activity were also used for defining activities in the other assays including the sPLA2, LOX and COX enzyme inhibitor activity assays in this article.

The results demonstrated that only the sub fraction of herbal concoction 1 showed good activity $(38.031 \mu \mathrm{g} /$ $\mathrm{mL})$. This activity was higher than the positive control Lamivudine $(40.90 \mu \mathrm{g} / \mathrm{mL})$ (Table 2$)$. This activity of the sub fraction of herbal concoction 1 suggested that it may be able to inhibit the early phases of the HIV-1 replicative cycle that is mediated by the HIV-RT. Ndhlala et al. [31] reported high HIV-RT inhibitory effects of aqueous herbal concoctions sold in KwaZulu-Natal (South Africa). Moreover, Matotoka et al. [32] reported the in vitro inhibition of HIV-1 reverse transcriptase of some herbal concoctions sold in the Limpopo Province. The rest of the other samples as obtained from the two fermented herbal concoctions exhibited variable activity against anti-HIV (Table 2) with crude sample of herbal concoction 1, crude and sub fraction (80\% acetone) of herbal concoction 2 exhibiting moderate activity with $\mathrm{IC}_{50}$ values ranging from 56.112 to $88.323 \mu \mathrm{g} / \mathrm{mL}$. The differences in activity of the concoctions may stem from the manner of preparation procedures taken to prepare the herbal constituents.

The $\mathrm{IC}_{50}$ results for the sPLA2 inhibitor activity assay are represented in Table 2 . The results indicated that the tested extracts had $\mathrm{IC}_{50}$ values lower than the positive control. The inhibition of sPLA2 activity can be a beneficial towards the progression of HIV and cancer because of lower levels of free arachidonic acid. Free arachidonic acids are metabolised into eicosanoids by LOX and COX enzymes, resulting in the proliferation of acute inflammation [38] which may accelerate the progression of many diseases and conditions including HIV and cancer. Both crude and sub fraction of herbal concoction 2 expressed notable inhibitory activity against sPLA2 with $\mathrm{IC}_{50}$ values of the two being closely around $15 \mu \mathrm{g} / \mathrm{mL}$ when compared to the samples derived from the reconstitutes of herbal concoction 1. The lowest activity against sPLA2 was recorded for crude concoction 1 with an $\mathrm{IC}_{50}$ value around $70 \mu \mathrm{g} / \mathrm{mL}$ (Table 2).

The inhibition of 15-LOX was used to determine the anti-inflammatory activity of the extracts with the results expressed as $\mathrm{IC}_{50}$ values (Table 2). The free arachidonic acid released by the activity of sPLA2 is metabolised by 15-LOX to form HETE which results in the proliferation of atherosclerotic plaque formation. The results indicated that the tested concoctions had $\mathrm{IC}_{50}$ values ranging from 88 to $42 \mu \mathrm{g} / \mathrm{mL}$ (Table 2). The sub fraction of herbal concoction 2 expressed the highest inhibitory activity against $15-\mathrm{LOX}$ with an $\mathrm{IC}_{50}$ value around $42 \mu \mathrm{g} /$ $\mathrm{mL}$.

The inhibition of COX-1 and COX-2 was also used to indicate the anti-inflammatory activity of the extracts with the results expressed as $\mathrm{IC}_{50}$ values (Table 2). The tested extracts exhibited high activities even though they were low when compared to the positive control against COX-1 activity. Extracts with high inhibitory activity against COX-1 are a concern due to reported beneficial effects associated with COX-1 activity compared to its inhibition [39]. In this case, all the samples exhibited high inhibiting activity against $\mathrm{COX}-1$ with $\mathrm{IC}_{50}$ values of 2.11 and $6.73 \mu \mathrm{g} / \mathrm{mL}$. The COX-1 enzyme initiates the production of beneficial prostaglandins responsible for

Table 2 HIV-1 reverse transcriptase activity and anti-inflammatory properties of some fermented herbal concoctions sold in Limpopo

\begin{tabular}{|c|c|c|c|c|c|}
\hline Sample & HIV-RT $1\left(\mathrm{IC} \mathrm{C}_{50} \mu \mathrm{g} / \mathrm{mL}\right)$ & sPLA2 $\left(\mathrm{IC}_{50} \mu \mathrm{g} / \mathrm{mL}\right)$ & 15-LOX $\left(I C_{50} \mu \mathrm{g} / \mathrm{mL}\right)$ & COX-1 (IC $50 \mu \mathrm{g} / \mathrm{mL})$ & COX-2 $\left(I_{50} \mu \mathrm{g} / \mathrm{mL}\right)$. \\
\hline C1 (Crude) & $64.4 \pm 2.1^{b}$ & $70.4 \pm 0.1^{a}$ & $88.2 \pm 0.2^{a}$ & $2.11 \pm 0.01^{d}$ & $18.00 \pm 0.01^{d}$ \\
\hline C1 (80\% Acetone) & $39.5 \pm 1.6^{\mathrm{de}}$ & $25.1 \pm 1.3^{b}$ & $67.2 \pm 0.6^{d}$ & $5.43 \pm 0.05^{b}$ & $27.60 \pm 0.02^{b}$ \\
\hline C2 (Crude) & $86.1 \pm 1.8^{\mathrm{a}}$ & $15.5 \pm 0.6^{c}$ & $56.1 \pm 0.3^{c}$ & $3.67 \pm 0.02^{c}$ & $22.10 \pm 0.01^{c}$ \\
\hline C2 (80\% Acetone) & $54.5 \pm 1.5^{c}$ & $15.3 \pm 0.5^{c}$ & $42.3 \pm 0.1^{d}$ & $6.72 \pm 0.01^{\mathrm{a}}$ & $34.10 \pm 0.01^{\mathrm{a}}$ \\
\hline Lamivudine & $41.0 \pm 0.2^{d}$ & & & & \\
\hline Zidovudine & $24.9 \pm 0.6^{9}$ & & & & \\
\hline Lopinavir & $33.8 \pm 0.5^{f}$ & & & & \\
\hline Ritonavir & $36.5 \pm 0.3^{\mathrm{ef}}$ & & & & \\
\hline Thioetheramide-PC & & $1.52 \pm 0.1^{d}$ & & & \\
\hline Nordihydroguairetic acid & & & $10.8 \pm 0.1^{e}$ & & \\
\hline Indomethacin & & & & $0.59 \pm 0.01^{\mathrm{e}}$ & $8.70 \pm 0.10^{e}$ \\
\hline
\end{tabular}


the maintenance and protection of the intestinal mucosal layer [40]. In the absence of COX-1, the mucosal layer is exposed and could result in ulceration. Therefore, there presence a challenge and negativity in use of these herbal concoctions due to persistent ulcerations associated with the inhibition of COX-1 activity.

However, the lower activities against sPLA2 encountered, necessitate exploration of other mechanisms by which the extracts may induce their inhibitory effect against the enzyme.

Most phytochemicals are foreign to the human body, therefore, the use of these bioactive compounds can be accompanied by detrimental toxicities and/or adverse effects that may impact the morbidity and mortality rate of the global populace. In this study, a colorimetric cell viability assay was used to determine the toxicological effects of herbal concoctions, where the tetrazolium salt 3-[4,5-dimethylthiazol-2-yl]-2,5-diphenyltetrazolium bromide (MTT) was used as an indicator. This salt is converted to an insoluble purple formazan by metabolically active cells. The tetrazolium ring is cleaved by succinate dehydrogenase found in the mitochondria. Due to the impermeability of the resulting formazan, this purple product is collected inside healthy cells. Upon resuspension, the absorbance of the purple colour displays the number of viable cells that are estimated [41]. This method is easy to use, safe, has a high reproducibility, and is widely used to determine both cell viability and cytotoxicity tests [42]. Moreover, In vitro cytotoxicity and/or cell viability assays have some advantages, such as speed, reduced cost and potential for automation, and tests using human cells may be more relevant than some In vivo animal tests $[42,43]$.
Cytotoxicity and anti-cancer outcomes of the consumption of the concoctions, were tested using normal human hepatoma cell lines (C3A) and human colon (HT-29) cancer cells. The percentage cytotoxicity and anti-cancer cell viability of herbal concoctions tested is represented in Fig. 1. A general observation after the 24 $\mathrm{h}$ incubation of the treated cell lines was that the viability of the cells was not entirely dependent on the increase and decrease of the concentrations and it was observed that there was no high consistency of the increase and decrease in cell viability percentages for both H-T29 and C3A cells. Overall, both concoction 1 and concoction 2 appeared to possess some very slight toxicity against cells in their crude form but the toxicity was very less in C3A. Both concoctions had potential anti-cancer properties at the concentrations of 700 and $800 \mu \mathrm{g} / \mathrm{ml}$. It can be concluded that crude concoction 1 is not toxic against normal C3A cells at lower concentrations (Fig. 1). All C3A cells treated with sub fractions of concoction 2 were displaying very high percentages of viability at all the concentrations. Crude concoction 1 proved to be more toxic at higher concentrations $(800 \mu \mathrm{g} / \mathrm{ml})$ displaying a low percentage of cell viabilities against C3A (Fig. 1). However, this was not the case for HT-29 cancer cells (Fig. 1) which were not affected at of the same concentration. The crude concoction 2 proved to be highly toxic at 300 and $400 \mu \mathrm{g} / \mathrm{ml}$ concentrations displaying the lowest percentages of cell viabilities against HT-29 cancer cells as compared to its other concentrations. Moreover, it should be noted that both C3A and HT-29 have almost similar results of cell toxicity levels at the concentrations of 300 and $400 \mu \mathrm{g} / \mathrm{ml}$. As the concentrations increased further, the crude concoction 2 proved to be more toxic against normal C3A cells

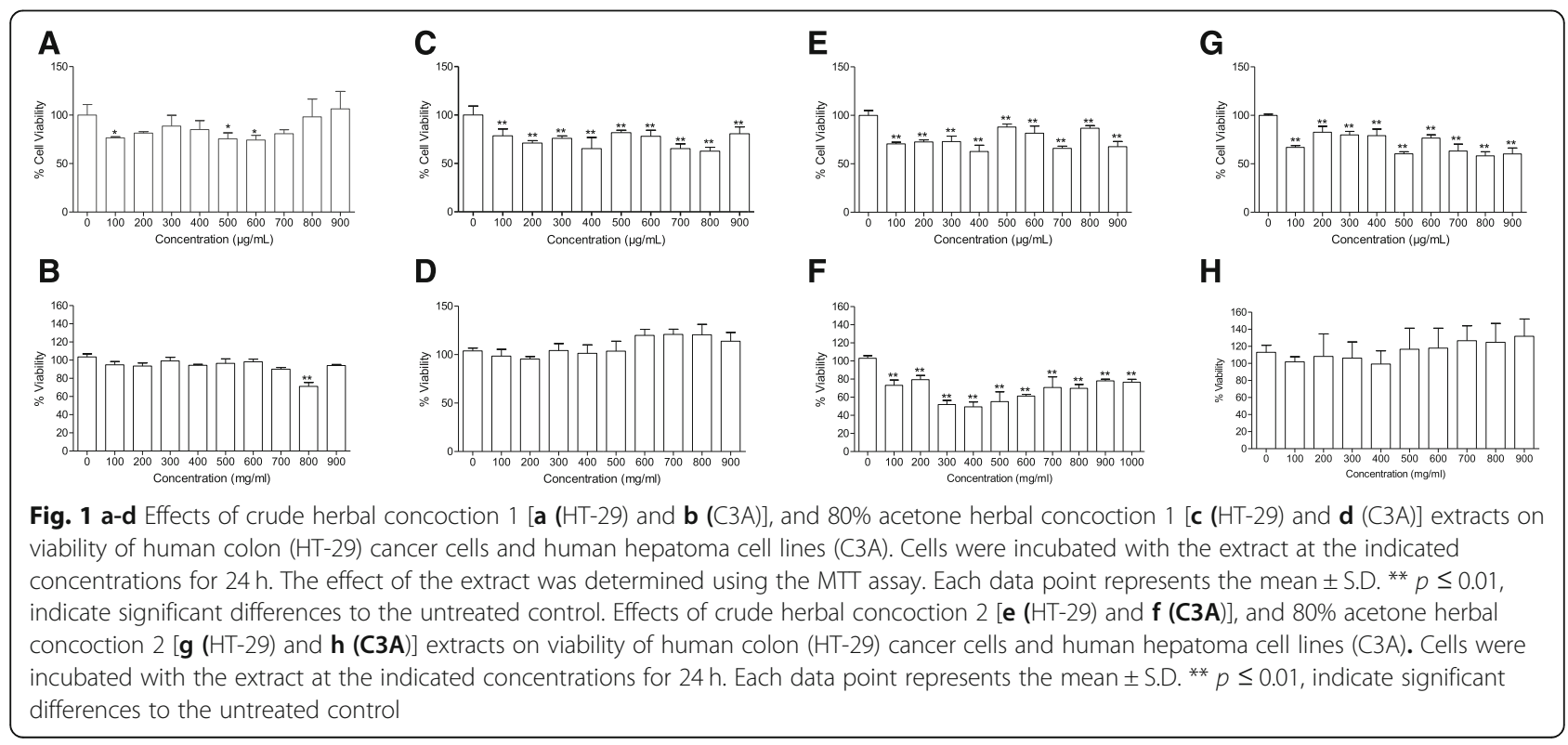


Table 3 Major chemical constituents in the plant species used as ingredients of two fermented commercial herbal concoctions

\begin{tabular}{|c|c|c|}
\hline $\begin{array}{l}\text { Herbal } \\
\text { Mixture }\end{array}$ & $\begin{array}{l}\text { Scientific } \\
\text { name }\end{array}$ & Chemical composition \\
\hline \multirow[t]{18}{*}{1} & \multirow{13}{*}{$\begin{array}{l}\text { Monsonia } \\
\text { angustifolia } \\
\text { E.Mey. ex } \\
\text { A.Rich. }\end{array}$} & Triterpenoids (ursolic acid and oleanolic acid) \\
\hline & & Cardiac glycosides \\
\hline & & Steroids \\
\hline & & Tannins \\
\hline & & $\begin{array}{l}\text { Justicidin A [9-(1',3'-benzodioxol-5'-yl)-4,6,7- } \\
\text { trimethoxynaphtho[2,3-c]furan-1(3H)-one] }\end{array}$ \\
\hline & & $\begin{array}{l}\text { 5-Methoxyjusticidin A [9-(1',3'-benzodioxol-5'-yl)- } \\
4,5,6,7 \text {-tetramethoxynaphtho[2,3-c]furan-1(3H)- } \\
\text { one] }\end{array}$ \\
\hline & & $\begin{array}{l}\text { Chinensinaphthol [9-(3',4'-dimethoxyphenyl)-4- } \\
\text { hydroxy-6,7-methylenedioxynaphtho[2,3-c]furan- } \\
\text { (3H)-one] }\end{array}$ \\
\hline & & $\begin{array}{l}\text { Retrochinensinaphthol methyl ether [4-(3',4'- } \\
\text { dimethoxyphenyl)-9-methoxy-6,7- } \\
\text { methylenedioxynaphtho[2,3-c]furan-1(3H)-one] }\end{array}$ \\
\hline & & $\begin{array}{l}\text { Suchilactone [3-(1',3'-benzodioxol-5'- } \\
\text { ylmethylene)-4-(3",4"- } \\
\text { dimethoxybenzyl)dihydrofuran-2(5H)-one] }\end{array}$ \\
\hline & & Secoisolariresinol \\
\hline & & Matairesinol \\
\hline & & Podophyllotoxin \\
\hline & & Desoxypodophyllotoxin \\
\hline & \multirow[t]{5}{*}{$\begin{array}{l}\text { Olea europaea } \\
\text { L. }\end{array}$} & Oleuropein \\
\hline & & Caffeic acid-C-hexoside \\
\hline & & Coumaric acid \\
\hline & & Citric acid \\
\hline & & Hydroxytyrosol \\
\hline
\end{tabular}

Activity

Anti-inflammatory and antitumour activities

Anti-inflammatory

Anti-inflammatory and antitumour activities

Antitumor activity, antiviral activity, and inhibition of active oxygen, such as inhibition of lipid peroxidation and lipoxygenase, xanthine oxidase, and monoamine oxidase

Antifungal, antiviral and antibacterial activities

Anticholinesterase

Anthelmintic activity

Antioxidant activity

Antioxidant activity

Anticancer, Antidiabetes, and protective against heart diseases

Antineoplastic and antiviral properties

Antitumor and anti-inflammatory activities

$[48,49]$

Antioxidant, antiinflammatory, anti-atherogenic, anticancer, antimicrobial and antiviral activity

Antioxidant, antiinflammatory

$[48,50]$

[51-53]

Antioxidant, anti-inflammatory activity

Antioxidant activity

Verbascoside

elenolic acid

ligstroside

Gallic acid

Rutin

Apigenin-7-Glucoside

Quercetin

Ferulic acid

Kaempferol

Luteolin
Anti-inflammatory, anti-tumor, antiviral, antibacterial and antifungal properties

Antioxidant, anti-inflammatory and antineoplastic properties

Antioxidant, antiinflammatory, anti-atherogenic, anticancer, antimicrobial and antiviral activity

Antioxidant activity

$[54,56]$

Antioxidant, anti-inflammatory, and antineoplastic properties

Anti-bacterial, anti-inflammatory, analgesic, anti-radiation, antioxidant, anti-myocardial hypoxia activity

$[51,52$,

Anti-inflammatory, antioxidant activity

$[51,52$,

Anti-inflammatory, antioxidant activity

Anti-inflammatory, antimicrobial, anticancer, antiarrhythmic, and antithrombotic activity, antidiabetic effects and immunostimulant properties

Antioxidant, anti-inflammatory, antimicrobial, anticancer, cardioprotective, neuroprotective, antidiabetic, antiosteoporotic, antiestrogenic activities

Antioxidant activity

Antitumor, antiviral, anti-inflammatory, and antibacterial 
Table 3 Major chemical constituents in the plant species used as ingredients of two fermented commercial herbal concoctions (Continued)

\begin{tabular}{|c|c|c|c|c|}
\hline $\begin{array}{l}\text { Herbal } \\
\text { Mixture }\end{array}$ & $\begin{array}{l}\text { Scientific } \\
\text { name }\end{array}$ & Chemical composition & Activity & Reference \\
\hline & \multirow{2}{*}{$\begin{array}{l}\text { esculentum } \\
\text { Mill. }\end{array}$} & & activities & \\
\hline & & cineole & Inflammatory & {$[61,63]$} \\
\hline & \multirow[t]{8}{*}{ Vitis vinifera $\mathrm{L}$} & Resveratrol (3,40,5-trihydroxystilbene) & Cyclooxygenase activity & [64] \\
\hline & & Gallic acid & $\begin{array}{l}\text { Antioxidant, anti-inflammatory, and antineoplastic } \\
\text { properties }\end{array}$ & {$[63,64]$} \\
\hline & & Catechin & $\begin{array}{l}\text { Antioxidant, antibacterial, antifungal, antidiabetic, anti- } \\
\text { inflammatory, antiproliferative and antitumor properties }\end{array}$ & [64-66] \\
\hline & & Proanthocyanidins & $\begin{array}{l}\text { Antioxidant, antibacterial, antifungal, antidiabetic, anti- } \\
\text { inflammatory, antiproliferative and antitumor properties }\end{array}$ & [66-68] \\
\hline & & Quercetin-O-pentoside & Anti-inflammatory, antioxidant activity & [65] \\
\hline & & Petunidin-3-O-glucoside & $\begin{array}{l}\text { Antioxidant, a-glucosidase and xanthine oxidase inhibitory } \\
\text { activities }\end{array}$ & {$[65]$} \\
\hline & & Rutin & $\begin{array}{l}\text { Anti-bacterial, anti-inflammatory, analgesic, anti-radiation, } \\
\text { antioxidant, anti-myocardial hypoxia activity }\end{array}$ & {$[52,69]$} \\
\hline & & Caftaric acid & $\begin{array}{l}\text { Antioxidant, anti-inflammatory, antimutagenic and anticar- } \\
\text { cinogenic, hepatoprotective, anti-diabetic, anti- } \\
\text { hypertensive, anti-obesity, anti-metabolic syndrome and } \\
\text { neuroprotective effects. }\end{array}$ & {$[69,70]$} \\
\hline & \multirow{10}{*}{$\begin{array}{l}\text { Moringa } \\
\text { oleifera Lam. }\end{array}$} & Quercetin, & Anti-inflammatory, antioxidant activity & {$[71,72]$} \\
\hline & & Kaempferol & $\begin{array}{l}\text { Antioxidant, anti-inflammatory, antimicrobial, anticancer, } \\
\text { cardioprotective, neuroprotective, antidiabetic, anti- } \\
\text { osteoporotic, antiestrogenic activities }\end{array}$ & $\begin{array}{l}{[51,60,72,} \\
73]\end{array}$ \\
\hline & & Ellagic acid & $\begin{array}{l}\text { Antioxidant, anti-inflammatory, and antineoplastic } \\
\text { properties }\end{array}$ & [72] \\
\hline & & Gallic acid & $\begin{array}{l}\text { Antioxidant, anti-inflammatory, and antineoplastic } \\
\text { properties }\end{array}$ & {$[64,72]$} \\
\hline & & Ferulic acid, & $\begin{array}{l}\text { Anti-inflammatory, antimicrobial, anticancer, anti- } \\
\text { arrhythmic, and antithrombotic activity, antidiabetic effects } \\
\text { and immunostimulant properties }\end{array}$ & {$[59,72]$} \\
\hline & & Chlorogenic acid & Anti-inflammatory, antimicrobial, anticancer & {$[72]$} \\
\hline & & Niazimicin & Anti-inflammatory, antimicrobial, anticancer & [72] \\
\hline & & Rutin & $\begin{array}{l}\text { Anti-bacterial, anti-inflammatory, analgesic, anti-radiation, } \\
\text { antioxidant, anti-myocardial hypoxia activity }\end{array}$ & {$[52,69]$} \\
\hline & & Moringin & $\begin{array}{l}\text { Antioxidant, anti-carcinogenic, anti-diabetic, anti- } \\
\text { inflammatory and anti-hypertensive properties }\end{array}$ & [74] \\
\hline & & Rutin & $\begin{array}{l}\text { Anti-bacterial, anti-inflammatory, analgesic, anti-radiation, } \\
\text { antioxidant, anti-myocardial hypoxia activity }\end{array}$ & $\begin{array}{l}{[52,69,} \\
72]\end{array}$ \\
\hline
\end{tabular}

than HT-29 cancer cells. Acute toxicity seems likely on crude concoction 2. Hence, all concoctions proved to possess activity against HT-29 cancerous cells as toxicity was found to be common in all tested concoctions. The anti-cancer activity of the concoctions does not result in toxicity against normal human cells; hence more work is needed to understand the mechanisms of action involved in cell selection.

The major chemical composition of the plant constituency of the two herbal mixtures are presented in Table 3. The main class of compounds gathered from literature are the phenolic compounds which in many studies are have attributed to anti-inflammation, anticancer and a lot other functionalities. Chief amongst these phenolic compounds are quercetin, kaempferol, ellagic acid, gallic acid and ferulic acid which all are known antioxidants [71, 72, 75]. Herbal mixture number two contains plant species which has rutin, Vitis vinifera L. and Moringa oleifera Lam., which is an important plant metabolite with vast pharmacological properties including anti-bacterial, anti-inflammatory, analgesic, anti-radiation, antioxidant and anti-myocardial hypoxia activity [73]. Some of these properties have been cited as the prime use of the herbal mixture and activity have been confirmed in the tests done in this and other studies. 
On the other hand, herbal Mixture number one contains Monsonia angustifolia E.Mey. ex A.Rich. and Olea europaea L., both of which contains a planthera of pharmacologically active metabolites like matairesinol, oleuropein, hydroxytyrosol and elenoic acid with strong anti-inflammatory and anti-cancer activity. Olea europaea also contains rutin amongst many other compounds which as mentioned earlier has vast pharmacological activities. These and other compounds listed here could form the bases of the activities observed in the herbal mixtures.

Khorombi [76], investigated the anticancer properties of $M$. angustifolia extracts in vitro against three highly sensitive cancer cell lines, namely melanoma UACC62, renal TKIO and breast MCF7. They reported a significant inhibition of the growth of cancer cells by the organic (methanol:dichloromethane, 1:1 v/ v) extract. In another study, Guo et al. [51], reported the beneficiary effect of fermenting $O$. europaea which results in conversion of oleuropein into hydroxytyrosol (HT), elenolic acid glucoside (oleoside-11methyl ester) and oleuropein aglycone. These compounds have been shown to exhibit Antioxidant, antiinflammatory, anti-atherogenic, anti-cancer, antimicrobial and antiviral activity [51, 52]. The fermentation of the herbal mixture with $O$. europaea could result in the production of these compounds which could contribute to the use of the mixtures.

\section{Conclusion}

The antiviral activity of one of the herbal concoctions was higher than one of the pharmaceutical standards used for the treatment of HIV-1. Hence displaying some potential inhibition against HIV-1 RT. There was variation in the anti-inflammation activity as determined by the sPL2, 15-LOX and COX enzyme assays. The only concerning matter was the high COX-1 activity in some of the extracts, which is not desirable due to the mucosal protection action of COX-1 enzyme. The toxicological results found in this study suggest that the concoctions might likely not be toxic to human cells upon consumption except for the crude concoction 2 which appeared to show a high percentage of toxicity. Moreover, the obtained data suggested that the concoctions are selectively toxic against HT-29 cancerous cells rather than normal C3A cells. Therefore, the herbal concoctions do display valid pharmacological potential. However, more work is needed to explore more on the anti-cancer activity and mechanisms of action thereof.

\section{Acknowledgements}

We acknowledge Mr. MS Mathebula for supplying the herbal concoctions, Ms. KM Malemela for assisting with cytotoxicity work, Ms. RG Kudumela for proofreading the manuscript.

\section{Authors' contributions}

MIN, carried out the cytotoxicity work, analysed the data and drafting of the manuscript. ARN, Anti-HIV test and anti-inflammatory tests, PM, study design, assisted in data analysis and interpretation as well as drafting of the manuscript. All authors read and approved the final manuscript.

\section{Funding}

The authors wish to thank the NRF (Reference: SFH150709124813; Grant No: 81341 and University of Limpopo (Grant no: 624) for financial support as well as the Department of Science and Innovations - Indigenous Knowledge System -based Tech Innovation, Pretoria, for supporting the study.

Availability of data and materials

The datasets used and/or analyzed during the current study are available from the corresponding author on reasonable request.

\section{Declarations}

Ethics approval and consent to participate Not applicable.

Consent for publication

Not applicable.

\section{Competing interests}

The authors declare that they have no known competing financial interests or personal relationships that could have appeared to influence the work reported in this paper

Received: 12 January 2021 Accepted: 12 May 2021

Published online: 26 May 2021

References

1. Barboza GE, Cantero JJ, Núñez C, Pacciaroni A, Ariza Espinar L. Medicinal plants: a general review and a phytochemical and ethnopharmacological screening of the native argentine Flora. Kurtziana. 2009;34(1-2):7-365.

2. Lall N, Kishore N. Are plants used for skin care in South Africa fully explored? J Ethnopharmacol. 2014;153(1):61-84. https://doi.org/10.1016/j. jep.2014.02.021.

3. Street RA, Stirk WA, Van Staden J. South African traditional medicinal planttrade challenges in regulating quality, safety and efficacy. J Ethnopharmacol. 2008;119(3):705-10. https://doi.org/10.1016/j.jep.2008.06.019.

4. Torri MC. Perceptions and uses of plants for reproductive health among traditional midwives in Ecuador: moving towards intercultural pharmacological practices. Midwifery. 2013;29(7):809-17. https://doi.org/10.1 016/j.midw.2012.06.018.

5. Armijos C, Gilardoni G, Amay L, Lozano A, Bracco F, Ramirez J, et al. Phytochemical and ethnomedicinal study of Huperzia species used in the traditional medicine of Saraguros in southern Ecuador; AChE and MAO inhibitory activity. J Ethnopharmacol. 2016;193:546-54. https://doi.org/10.1 016/j.jep.2016.09.049

6. Ballesteros JL, Bracco F, Cerna M, Vita Finzi P, Vidari G. Ethnobotanical research at the Kutukú Scientific Station, Morona-Santiago, Ecuador. Biomed Res Int. 2016;2016:9105746.

7. Baytop T. Therapy with medicinal plants in Turkey (past and present). Istanbul: Publication of the Istanbul University; 1999. p. 312.

8. Van Wyk BE, Oudtshoorn BV, Gericke N. Medicinal plants of South Africa. Pretoria: Briza Publications; 2009.

9. Lemoine M, Nayagam S, Thursz M. Viral hepatitis in resource-limited countries and access to antiviral therapies: current and future challenges. Futur Virol. 2013;8(4):371-80. https://doi.org/10.2217/fvl.13.11.

10. Cano $\mathrm{JH}$, Volpato $\mathrm{G}$. Herbal mixtures in the traditional medicine of eastern Cuba. J Ethnopharmacol. 2004;90(2-3):293-316. https://doi.org/10.1016/j. jep.2003.10.012

11. Ndhlala AR, Stafford Gl, Finnie JF, Van Staden J. In vitro pharmacological effects of manufactured herbal concoctions used in KwaZulu-Natal South Africa. J Ethnopharmacol. 2009;122(1):117-22. https://doi.org/10.1016/j.jep.2 008.12.017.

12. Matotoka MM, Masoko P. Phytochemical screening and pharmacological evaluation of herbal concoctions sold at Ga Maja Limpopo province. S Afr J Bot. 2018;117:1-10. https://doi.org/10.1016/j.sajb.2018.04.013. 
13. Pujol J. The herbalist handbook: African Flora medicinal plants. Durban: Natural Healers Foundation; 1990. p. 23.

14. Parvez S, Malik KA, Ah Kang S, Kim HY. Probiotics and their fermented food products are beneficial for health. J Appl Microbiol. 2006;100(6):1171-85. https://doi.org/10.1111/j.1365-2672.2006.02963.x.

15. Carmona MD, Llorach R, Obon C, Rivera D. "Zahraa", a Unani multicomponent herbal tea widely consumed in Syria: components of drug mixtures and alleged medicinal properties. J Ethnopharmacol. 2005;102(3): 344-50. https://doi.org/10.1016/j.jep.2005.06.030.

16. UNAIDS., 2018. Global HIV \& AIDS statistics -2018 fact sheet. http://www. unaids.org/en/resources/fact-sheet. (Accessed 15 Feb 2020).

17. Sidibé M, Loures L, Samb B. The UNAIDS 90-90-90 target: a clear choice for ending AIDS and for sustainable health and development. J Int AIDS Soc. 2016;19(1):225-45.

18. Kisangau DP, Lyaruu HV, Hosea KM, Joseph CC. Use of traditional medicines in the management of HIV/AIDS opportunistic infections in Tanzania: a case in the Bukoba rural district. J Ethnobiol Ethnomed. 2007;3(1):29.

19. Moodley K, Rossouw T, Staunton C, Colvin CJ. Synergies, tensions, and challenges in HIV prevention, treatment and cure research: exploratory conversations with HIV experts in South Africa. BMC Medical Ethics. 2016; 17(1):26.

20. Nondo RS, Moshi MJ, Erasto P, Zofou D, Njouendou AJ, Wanji S, et al. Evaluation of the cytotoxic activity of extracts from medicinal plants used for the treatment of malaria in Kagera and Lindi regions, Tanzania. J Appl Pharmaceut Sci. 2015;5(4):007-12.

21. Fotakis $\mathrm{G}$, Timbrell JA. In vitro cytotoxicity assays: comparison of $\mathrm{LDH}$, neutral red, MTT and protein assay in hepatoma cell lines following exposure to cadmium chloride. Toxicol Lett. 2006;160(2):171-7. https://doi. org/10.1016/j.toxlet.2005.07.001.

22. Ferlay J, Soerjomataram I, Ervik M, Dikshit R, Eser S, Mathers C, et al. GLOBOCAN 2012 v1.0, cancer incidence and mortality worldwide: IARC CancerBase no. 11 [internet]. Lyon: International Agency for Research on Cancer; 2013. Available from: http://globocan.iarc.fr/Pages/fact_sheets_ca ncer. (Accessed 15 Feb 2020)

23. Foo JB, Yazan LS, Tor YS, Wibowo A, Ismail N, How CW, et al. Induction of cell cycle arrest and apoptosis by betulinic acid-rich fraction from Dillenia suffruticosa root in MCF-7 cells involved p53/p21 and mitochondrial signalling pathway. J Ethnopharmacol. 2015;166:270-8. https://doi.org/10.1 016/j.jep.2015.03.039.

24. Lodish H, Berk A, Zipursky SL, et al. Molecular Cell Biology. 4th edition. New York: W. H. Freeman; 2000. Section 24.1, Tumor Cells and the Onset of Cancer. Available from: https://www.ncbi.nlm.nih.gov/books/ NBK21590/.

25. Anusha S, Mohan CD, Ananda H, Baburajeev CP, Rangappa S, Mathai J, et al. Adamantyl-tethered-biphenylic compounds induce apoptosis in cancer cells by targeting Bcl homologs. Bioorg Med Chem Lett. 2016;26(3):1056-60. https://doi.org/10.1016/j.bmcl.2015.12.026.

26. Moodley J, Stefan DC, Sewram V, Ruff P, Freeman M, Asante-Shongwe K. An overview of cancer research in south African academic and research institutions, 2013-2014. S Afr Med J. 2016;106(6):607-10. https://doi.org/10.71 96/SAMJ.2016.v106i6.10314.

27. Kumar CP, Reddy TS, Mainkar PS, Bansal V, Shukla R, Chandrasekhar S, et al. Synthesis and biological evaluation of 5, 10-dihydro-11H-dibenzo [b, e][1,4] diazepin-11-one structural derivatives as anti-cancer and apoptosis inducing agents. Eur J Med Chem. 2016;108:674-86. https://doi.org/10.1016/j. ejmech.2015.12.007.

28. Sponchiado G, Adam ML, Silva CD, Soley BS, de Mello-Sampayo C, Cabrini DA, et al. Quantitative genotoxicity assays for analysis of medicinal plants: a systematic review. J Ethnopharmacol. 2016;178:289-96. https://doi.org/10.1 016/j.jep.2015.10.026.

29. Desai AG, Qazi GN, Ganju RK, El-Tamer M, Singh J, Saxena AK, et al. Medicinal plants and cancer chemoprevention. Curr Drug Metab. 2008;9(7): 581-91. https://doi.org/10.2174/138920008785821657.

30. Dhanamani MDSL, Devi SL, Kannan S. Ethnomedicinal plants for cancer therapy-a review. Hygeia JD Med. 2011;3(1):1-10.

31. Ndhlala AR, Anthonissen R, Stafford Gl, Finnie JF, Verschaeve L, Van Staden $J$. In vitro cytotoxic and mutagenic evaluation of thirteen commercial herbal mixtures sold in KwaZulu-Natal, South Africa. S Afr J Bot. 2010;76(1):132-8. https://doi.org/10.1016/j.sajb.2009.09.010.

32. Matotoka MM, Ndhlala AR, Masoko P. In vitro inhibition of HIV-1 reverse transcriptase and anti-inflammatory activities of some herbal concoctions sold in the Limpopo Province. S Afr J Bot. 2019;126:65-9. https://doi.org/1 0.1016/j.sajb.2019.07.023

33. George A, Chinnappan S, Chintamaneni M, Kotak VC, Choudhary Y, Kueper $T$, et al. Anti-inflammatory effects of Polygonum minus (Huds) extract (Lineminus $^{\mathrm{TM}}$ ) in in-vitro enzyme assay and carrageenan induced paw edema. BMC Complement Altern Med. 2014;14(1):355-62. https://doi.org/1 0.1186/1472-6882-14-355.

34. Thibane VS, Ndhlala AR, Finnie JF, Van Staden J. Modulation of the enzyme activity of secretory phospholipase A2, lipoxygenase and cyclooxygenase involved in inflammation and disease by extracts from some medicinal plants used for skincare and beauty. S Afr J Bot. 2019;120:198-203. https:// doi.org/10.1016/j.sajb.2018.06.001.

35. Boudjou S, Oomah BD, Zaidi F, Hosseinian F. Phenolics content and antioxidant and anti-inflammatory activities of legume fractions. Food Chem. 2013;138(2-3):1543-50. https://doi.org/10.1016/j.foodchem.2012.11.108.

36. Mosmann T. Rapid colorimetric assay for cellular growth and survival: application to proliferation and cytotoxicity assays. J Immunol Methods. 1983;65(1-2):55-63. https://doi.org/10.1016/0022-1759(83)90303-4.

37. Chukwujekwu JC, Ndhlala AR, De Kock CA, Smith PJ, Van Staden J. Antiplasmodial, HIV-1 reverse transcriptase inhibitory and cytotoxicity properties of Centratherum punctatum Cass. And its fractions. S Afr J Bot. 2014;90:17-9. https://doi.org/10.1016/j.sajb.2013.10.001.

38. Dennis EA, Cao J, Hsu YH, Magrioti V, Kokotos G. Phospholipase A2 enzyme: physical structure, biological function, disease implication, chemical inhibition and therapeutic intervention. Chem Rev. 2011;111(10):6130-85. https://doi.org/10.1021/cr200085w.

39. Suleyman H, Demircan B, Karagoz Y. Anti-inflammatory and side effects of cyclooxygenase inhibitors. Pharmacol Rep. 2007:59(3):247-58.

40. Dennis EA, Norris PC. Eicosanoid storm in infection and inflammation. Nat Rev Immunol. 2015;15(8):511-23. https://doi.org/10.1038/nri3859.

41. Kumar P, Nagarajan A, Uchil PD. Analysis of cell viability by the MTT assay. Cold Spring Harbour Protocols. 2018;2018(6):pdb.prot095505. https://doi. org/10.1101/pdb.prot095505.

42. Aslantürk ÖS, Çelik TA, Karabey B, Karabey F. Active phytochemical detecting, antioxidant, cytotoxic, apoptotic activities of ethyl acetate and methanol extracts of Galium aparine L. J Pharmaceutical Res Int. 2017;15(6): $1-16$.

43. Stone V, Johnston H, Schins RP. Development of in vitro systems for nanotoxicology: methodological considerations. Crit Rev Toxicol. 2009;39(7): 613-26. https://doi.org/10.1080/10408440903120975.

44. Snell ES. The pharmacological properties of corticosteroids in relation to clinical efficacy. Br J Dermatol. 1976;94(12):15-23. https://doi.org/10.1111/j.13 65-2133.1976.tb02265.x.

45. Okuda T, Yoshida T, Nayeshiro HG. A new ellagitannin from geranium Thunhergii. Tetrahedron Lett. 1976;41:3721-2.

46. Chun YS, Kim J, Chung S, Khorombi E, Naidoo D, Nthambeleni R, et al. Protective roles of Monsonia angustifolia and its active compounds in experimental models of Alzheimer's disease. J Agric Food Chem. 2017; 65(15):3133-40. https://doi.org/10.1021/acs.jafc.6b04451.

47. Fouche G, Sakong BM, Adenubi OT, Pauw E, Leboho T, Wellington KW, et al. Anthelmintic activity of acetone extracts from south African plants used on egg hatching of Haemonchus contortus. Onderstepoort J Vet Res. 2016; 83(1):a1164

48. Fouche G, Afolayan AJ, Wintola OA, Khorombi TE, Senabe J. Effect of the aqueous extract of the aerial parts of Monsonia angustifolia E. Mey. Ex a. rich., on the sexual behaviour of male Wistar rats. BMC Complement Altern Med. 2015:15:343.

49. Liu Y-Q, Yang L, Tian X. Podophyllotoxin: current perspectives. Current Bioactive Compounds. 2007:3(1):37-66.

50. Khaled SY, Ammori BJ, Elkod E. Increased levels of granulocytic myeloidderived suppressor cells in peripheral blood and tumour tissue of pancreatic cancer patients. J Immunology Res. 2014;2014:879897 pp. 9pages.

51. Guo Z, Jia X, Zheng Z, Lu X, Zheng Y, Zheng B, et al. Chemical composition and nutritional function of olive (Olea europaea L.): a review. Phytochem Rev. 2018;17(5):1091-110. https://doi.org/10.1007/s11101-017-9526-0.

52. Hashmi MA, Khan A, Hanif M, Farooq U, Perveen S. Traditional uses, Phytochemistry, and pharmacology of Olea europaea (olive). Evid Based Complement Alternat Med. 2015;541591:29.

53. Omar SH. Oleuropein in olive and its pharmacological effects. Sci Pharm. 2010;78(2):133-54. https://doi.org/10.3797/scipharm.0912-18. 
54. Fernández-Poyatos MP, Ruiz-Medina A, Llorent-Martínez EJ. Phytochemical profile, mineral content, and antioxidant activity of Olea europaea L. CV. Cornezuelo table olives. Influence of in vitro simulated gastrointestinal digestion. Food Chem. 2019;297:124933.

55. Nicolì F, Negro C, Vergine M, Aprile A, Nutricati E, Sabella E, et al. Evaluation of phytochemical and antioxidant properties of 15 Italian Olea europaea $\mathrm{L}$. cultivar leaves. Molecules. 2019;24:1-12.

56. Bertellia M, Kiani AK, Paolacci S, Manara E, Kurti D, Dhuli K, et al. Hydroxytyrosol: a natural compound with promising pharmacological activities. J Biotechnol. 2020;309:29-33. https://doi.org/10.1016/j.jbiotec.201 9.12.016.

57. Alipieva K, Korkina L, Orhan IE, Georgiev MI. Verbascoside - a review of its occurrence, (bio) synthesis and pharmacological significance. Biotechnol Adv. 2014;32(6):1065-76. https://doi.org/10.1016/j.biotecha dv.2014.07.001.

58. Maalej A, Bouallagui Z, Hadrich F, Isoda H, Sayadi S. Assessment of Olea europaea L. fruit extracts: phytochemical characterization and anticancer pathway investigation. Biomed Pharmacother. 2017;90:179-86. https://doi. org/10.1016/j.biopha.2017.03.034.

59. Zduńska K, Dana A, Kolodziejczak A, Rotsztejn H. Antioxidant properties of Ferulic acid and its possible application. Skin Pharmacol Physiol. 2018;31(6): 332-6. https://doi.org/10.1159/000491755.

60. Calderon-Montano JM, Burgos-Moron E, Perez-Guerrero C, Lopez-Lazaro M. A review on the dietary flavonoid Kaempferol. Mini-Rev Med Chem. 2011; 11(4):298-344. https://doi.org/10.2174/138955711795305335.

61. Kohli RK, Singh D. Allelopathic impact of volatile components from eucalyptus on crop plants. B1ologia Plantarum (PRAHA). 1991;33(6):475-83.

62. Mukhtar YM, Adu-Frimpong M, Xu X, Yu J. Biochemical significance of limonene and its metabolites: future prospects for designing and developing highly potent anticancer drugs. Biosci Rep. 2018;38(6): BSR20181253. https://doi.org/10.1042/BSR20181253.

63. Juergens UR. Anti-inflammatory properties of the monoterpene 1.8-cineole: current evidence for co-medication in inflammatory airway diseases. Drug Res (Stuttg). 2014;64(12):638-46. https://doi.org/10.1055/s-0034-1372609.

64. Yang J, Martinson TE, Liu RH. Phytochemical profiles and antioxidant activities of wine grapes. Food Chem. 2009;116(1):332-9. https://doi.org/10.1 016/j.foodchem.2009.02.021.

65. Corrêa RCCG, Haminiuk CWI, Barros L, Dias MI, Calhelha RC, Kato CG, et al. Stability and biological activity of merlot (Vitis vinifera) grape pomace phytochemicals after simulated in vitro gastrointestinal digestion and colonic fermentation. J Funct Foods. 2017;36:410-7. https://doi.org/10.1016/ j.jff.2017.07.030.

66. Coșarcă S, Tanase C, Muntean DL. Therapeutic aspects of catechin and its derivatives - an update. Acta Biologica Marisiensis ABMJ 2019. 2019;2(1):219. https://doi.org/10.2478/abmj-2019-0003.

67. Liang Z, Cheng L, Zhong G-Y, Liu RH. Antioxidant and Antiproliferative activities of twenty-four Vitis vinifera grapes. PLoS One. 2014;9(8):e105146. https://doi.org/10.1371/journal.pone.0105146.

68. Mirdehghan SH, Rahimi S. Pre-harvest application of polyamines enhances antioxidants and table grape (Vitis vinifera L.) quality during postharvest period. Food Chem. 2016;196:1040-7. https://doi.org/10.1016/j.foodchem.2 015.10.038.

69. Moldovan ML, Carpa R, Fizes I, Vlase L, Bogdan C, lurian SM, et al. Phytochemical profile and biological activities of tendrils and leaves extracts from a variety of Vitis vinifera L. Antioxidants. 2020;9:373.

70. Koriem KMM. Caftaric acid: an overview on its structure, daily consumption, bioavailability and pharmacological effects. Biointerface Res Appl Chem. 2020;10(3):5616-23.

71. Ndhlala A, Mulaudzi R, Ncube B, Abdelgadir H, du Plooy C, Van Staden J. Antioxidant, antimicrobial and phytochemical variations in thirteen Moringa oleifera lam. Cultivars. Molecules. 2014;19:10480.

72. Singh AK, Rana HK, Tshabalala T, Kumar R, Gupta A, Ndhlala AR, et al. Phytochemical, nutraceutical and pharmacological attributes of a functional crop Moringa oleifera lam: an overview. S Afr J Bot. 2020;129:209-20. https:// doi.org/10.1016/j.sajb.2019.06.017

73. Tshabalala T, Ndhlala AR, Ncube B, Abdelgadir H, Van Staden J. Potential substitution of the root with the leaf in the use of Moringa oleifera for antimicrobial, antidiabetic and antioxidant properties. S Afr J Bot. 2020;129: 106-12. https://doi.org/10.1016/j.sajb.2019.01.029.

74. Borgonovo G, De Petrocellis L, Moriello AS, Bertoli S, Leone A, Battezzati A, et al. Moringin, a stable Isothiocyanate from Moringa oleifera, activates the somatosensory and pain receptor TRPA1 channel in vitro. Molecules. 2020; 25(4):976. https://doi.org/10.3390/molecules25040976.

75. Tshabalala T, Ncube B, Madala NE, Nyakudya T, Moyo HP, Sibanda M, et al. Scribbling the cat: a case of the "miracle" plant, Moringa oleifera. Plants. 2019;8(11):510. https://doi.org/10.3390/plants8110510.

76. Khorombi TE. A chemical and pharmacological investigation of three south African plants; 2006. MSc Thesis, University of KwaZulu-Natal, Pietermaritzburg, School of Chemistry

\section{Publisher's Note}

Springer Nature remains neutral with regard to jurisdictional claims in published maps and institutional affiliations.
Ready to submit your research? Choose BMC and benefit from:

- fast, convenient online submission

- thorough peer review by experienced researchers in your field

- rapid publication on acceptance

- support for research data, including large and complex data types

- gold Open Access which fosters wider collaboration and increased citations

- maximum visibility for your research: over $100 \mathrm{M}$ website views per year

At BMC, research is always in progress.

Learn more biomedcentral.com/submissions 